https://doi.org/10.52058/2786-4952 -2022-1(6)-203-211

Копочинська Юлія Володимирівна доктор педагогічних наук, доцент, доцент кафедри фізичної терапії, ЗВО "Міжнародний науково-технічний університет імені академіка Юрія Бугая", Магнітогорський провулок, 3, м. Київ, 02000, https://orcid.org/0000-0001-5018-3747

Дмітрісва Ніколь Субханівна викладач кафедри фізичної терапії, 3ВО "Міжнародний науково-технічний університет імені академіка Юрія Бугая", Магнітогорський провулок, 3, м. Київ, 02000, https://orcid.org/0000-0001-6492-3371

Глиняна Оксана Олександрівна кандидат наук з фізичного виховання i спорту, доцент, доцент кафедри біобезпеки і здоров'я людини, Національний технічний університет України «Київський політехнічний інститут ім. Ігоря Сікорського», проспект Перемоги, 37, м. Київ, 03056, https://orcid.org/0000-0003-4118-0856

\title{
ЗАСТОСУВАННЯ ІНФОРМАЦІЙНИХ ТЕХНОЛОГІЙ У ПРОЦЕСІ ВИКЛАДАННЯ ТЕОРІЇ І ПРАКТИКИ ФІЗИЧНОЇ ТЕРАПІЇ
}

Анотація. Метою статті $є$ дослідження актуальності та ефективності застосування інформаційних технологій у викладанні теорії і практики фізичної терапії у професійної підготовки майбутніх фахівців. Сучасний розвиток вітчизняної вищої освіти характеризується появою нових освітніх напрямів та спеціальностей. На сучасному етапі розвитку суспільства фізична терапія є освітньо-професійною галуззю, що швидко розвивається в усіх країнах, в тому числі в Україні. Зважаючи на гостру потребу держави у фахівцях 3 фізичної терапії, вища освіта за цією спеціальністю має перспективи для подальшого розвитку. Використання інформаційних технологій викладання теорії і практики фізичної терапії $\epsilon$ одним із пріоритетних напрямків сьогодення. Інформаційні технології дозволяють удосконалювати методологію, зміст, методи та організаційні форми навчання 3 клінічних дисциплін, удосконалювати механізми управління педагогічним процесом. Сучасні інформаційні технології $\epsilon$ інструментом прискорення освітнього процесу, дозволяють створювати, зберігати та переробляти інформацію медичного призначення та представляти іiі студентам для навчання та оцінки рівня знань. Інформаційні технології дозволяють давати ілюстрації найважливіших понять фізичної терапії. Це підвищення наочності, активізації пізнавальної діяльності студентів, поєднання механізмів вербальнологічного та образного мислення. Традиційні вимоги до навчальних занять (запам'ятати, вміти відтворити) трансформуються до базових інформаційних 
умінь типу пошуку знань (уміти знайти та застосувати під час вирішення поставлених завдань). Сучасні програми відкривають доступ передових джерел інформації - електронних підручників, освітніх сайтів та систем дистанційного навчання. При цьому здійснюється і особистісно-орієнтований розвиток усіх учасників педагогічного процесу: студентів та викладачів. Інформаційні технології вимагають від викладача розвитку спеціальних навичок, прийомів педагогічної роботи, значно підвищують вимоги до якості навчальних матеріалів, що розробляються, через відкритість доступу до них студентів, інших викладачів та експертів. Специфіка технології професійної підготовки, що застосовується під час викладання дисципліни "Теорія i практика фізичної терапії" проявляється в тому, що при проведенні заняття у вигляді "ситуаційного тренінгу" або розв'язання "ситуаційного завдання" можна досягти прогнозованих результатів. Робота в групі з аналізу ситуації дозволяє студентам не лише краще засвоїти матеріал, але й розглядати різноманітні можливості та підходи до вирішення того чи іншого практичного завдання чи проблеми.

Ключові слова: фізична терапія, професійна підготовка, інформаційні технології, теорія і практика фізичної терапії, професійна освіта.

Kopochynska Yuliia Volodymyrivna Doctor of Pedagogic Sciences, Associate Professor, Associate Professor of the Department of Physical Therapy Academician Yuriy Bugay International Scientific and Technical University, Magnitogorsk Lane, 3, Kyiv, 02000, https://orcid.org/0000-0001-5018-3747

Dmitriieva Nikol Subkhanivna Lecturer at the Department of Physical Therapy Academician Yuriy Bugay International Scientific and Technical University, Magnitogorsk Lane, 3, Kyiv, 02000, https://orcid.org/0000-0001-6492-3371

Glynyana Oksana Oleksandrivna Candidate of Science in Physical Education and Sports, Associate Professor, Associate Professor of the Department of Biosafety and Human Health National Technical University of Ukraine "I.Sikorsky Kyiv Polytechnic Institute", Prosp. Peremohy, 37, Kyiv, 03056, https://orcid.org/0000-0003-4118-0856

\section{APPLICATION OF INFORMATION TECHNOLOGIES IN THE PROCESS OF TEACHING THEORY AND PRACTICE OF PHYSICAL THERAPY}

Abstract. The aim of the article is to study the relevance and effectiveness of information technology in teaching the theory and practice of physical therapy in the training of future professionals. The modern development of domestic higher education is characterized by the emergence of new educational areas and specialties. At the present stage of development of society, physical therapy is an educational and professional field that is developing rapidly in all countries, 
including Ukraine. Given the urgent need of the state for specialists in physical therapy, higher education in this specialty has prospects for further development. The use of information technology in teaching the theory and practice of physical therapy is one of the priority areas today. Information technologies allow to improve the methodology, content, methods and organizational forms of teaching in clinical disciplines, to improve the mechanisms of management of the pedagogical process. Modern information technologies are a tool to accelerate the educational process, allow you to create, store and process medical information and present it to students for learning and assessment. Information technology allows to illustrate the most important concepts of physical therapy. This is an increase in visibility, activation of cognitive activity of students, a combination of mechanisms of verbal-logical and figurative thinking. Traditional requirements for training sessions (remembering, being able to reproduce) are transformed into basic information skills such as knowledge search (being able to find and apply in solving tasks). Modern programs open access to advanced sources of information - electronic textbooks, educational sites and distance learning systems. At the same time, the personality-oriented development of all participants in the pedagogical process is carried out: students and teachers. Information technologies require the teacher to develop special skills, methods of pedagogical work, significantly increase the requirements for the quality of educational materials being developed, through open access to them by students, other teachers and experts. The specificity of the technology of professional training used in the teaching of the discipline "Theory and practice of physical therapy" is manifested in the fact that when conducting classes in the form of "situational training" or solving "situational tasks" can achieve predictable results. Working in a situation analysis group allows students not only to better master the material, but also to consider a variety of opportunities and approaches to solving a practical problem or problem.

Keywords: physical therapy, vocational training, information technology, theory and practice of physical therapy, vocational education.

Постановка проблеми. У сучасних умовах дедалі більше зростає роль i важливість інноваційних форм та технологій навчання у сфері охорони здоров'я. Традиційні форми навчання поступаються місцем інноваційним засобам, що дає можливість викладачеві максимально раціонально використовувати час заняття та дозволяє легко залучити до навчального процесу учнів, а студенту проявити себе під час самостійної роботи $[1,5,7]$. Сутність інтерактивного навчання в тому, що навчальний процес організується таким чином, що практично всі студенти виявляються залученими до пізнавальної діяльності $[2,3,6]$. Впровадження нових інформаційних технологій навчання дозволяє адаптувати студентів до реальних ситуацій у практичній діяльності фізичного терапевта та випускати фахівців, які отримали високий рівень професійної підготовки.

Сучасний розвиток вітчизняної вищої освіти характеризується появою 
нових освітніх напрямів та спеціальностей. Однією 3 таких спеціальностей у галузі охорони здоров'я є спеціальність 227 “Фізична терапія, ерготерапія”. Реформи в галузі охорони здоров'я, які відбуваються в Україні, пред’являють нові вимоги до фахівців з фізичної терапії. Відповідно, об'єктивно зростає значення розвитку професіоналізму цих фахівців i підвищення їх конкурентоспроможності. На сучасному етапі розвитку суспільства фізична терапія $\epsilon$ освітньо-професійною галуззю, що швидко розвивається в усіх країнах, в тому числі в Україні. Зважаючи на гостру потребу держави у фахівцях 3 фізичної терапії, вища освіта за цією спеціальністю має перспективи для подальшого розвитку [1].

Освіта належить до найважливіших напрямків державної політики України. Відповідно до Національної стратегії розвитку освіти в Україні на 2012 - 2021 рр. освіта є стратегічним ресурсом духовного, культурного i соціально-економічного розвитку суспільства, підвищення рівня добробуту людей, забезпечення національних інтересів, формування позитивної репутації держави i зміцнення міжнародного авторитету, створення умов для самореалізації кожної особистості [1].

3 огляду на визначені пріоритети найважливішими для держави $\epsilon$ виховання людини інноваційного типу мислення та культури, проектування акмеологічного освітнього простору з урахуванням інноваційного розвитку системи освіти, запитів особистості, потреб суспільства і держави. Якісна освіта стає необхідною умовою формування нових життєвих орієнтирів особистості, забезпечення сталого розвитку суспільства, гуманізації суспільноекономічних [1].

Аналіз останніх досліджень і публікацій. Одним із сучасних напрямків розвитку активного навчання $€$ інтерактивні технології навчання. Поняття «інтерактивні технології» розглядається як сучасний етап розвитку активного навчання.

У сучасній педагогічній літературі представлені відмінні риси активного та інтерактивного навчання. Автори відзначають, що основним способом організації взаємодії викладача та учнів стає не тільки активний зворотний зв'язок між педагогом та учнями, а й організація взаємодії учнів між собою [2].

У психологічних дослідженнях зазначається, що інформаційні технології впливають на формування теоретичного творчого та модульнорефлексивного мислення учнів, що комп'ютерна візуалізація навчальної інформації істотно впливає на формування уявлень, що займають центральне місце в образному мисленні $[1,3,9]$, а образність уявлень у пам'яті учнів збагачує сприйняття навчального матеріалу, сприяючи його науковому розумінню [2, 4, 8]. У процесі навчання студенти набувають навичок роботи 3 інформацією медичного призначення, яка відноситься до здоров'я та його стану для конкретної людини, навчаються використовувати інформаційно-технологічні медичні системи. 
Мета статті - дослідження актуальності та ефективності застосування інформаційних технологій у викладанні теорії і практики фізичної терапії у професійної підготовки майбутніх фахівців.

Виклад основного матеріалу. На кафедрі фізичної терапії накопичено практичний досвід використання інформаційних технологій у викладанні дисципліни «Теорія і практика фізичної терапії»: рольові та ділові ігри, робота в групах, іноді - метод мозкового штурму та дискусії при обговоренні способів та методів фізичної терапії хворих з множинною та поєднаною травмою. Впроваджено технічні засоби навчання та контролю у вигляді комп'ютерного тестування за основними розділами спеціальності. Все це не замінює викладача на заняттях, а лише допомагає студенту самостійно вивчати та закріплювати знання з предмета, що вивчається. Впровадження інформаційних технологій змінюе звичні транслюючі форми навчання на діалогові, орієнтовані на взаємодію студента як з викладачем, а й один з одним [1]. Ми підтримуємо дані авторів у тому, що впровадження інформаційних технологій у навчання дозволяє вирішувати такі завдання:

- підвищення пізнавальної мотивації студентів та поява навичок самостійної навчальної діяльності, активна участь на практичних заняттях у засвоєнні нового матеріалу;

- підвищення навичок групового навчання;

- вміння працювати в команді та 3 командою (виконання індивідуальних та групових процедур кінезіотерапії) при здійсненні програми фізичної терапії пацієнта.

У чому ми бачимо переваги нових інформаційних технологій у педагогічному процесі? Це засвоєння навчального матеріалу студентами не як пасивних слухачів, а як активних учасників, коли йде засвоєння великого обсягу пропонованого матеріалу. Значно збільшується обсяг самостійної роботи студента 3 пацієнтами, отримання навичок та умінь обгрунтовувати свої думки, працювати у парі чи групі, формуються вміння самостійно знаходити корисну інформацію та розширювати кругозір учня. При цьому змінюється роль викладача як організатора педагогічного процесу та як консультанта у складних клінічних ситуаціях. На таких заняттях потрібно використовувати заздалегідь підготовлений матеріал, на що потрібна додаткова підготовка, знання комп'ютерних технологій та принципів використання інтерактивних технологій у педагогічному процесі.

Нові технології допомагають зняти нервове навантаження зі студентів, активізувати їхню увагу, здійснювати взаємне навчання з урахуванням досвіду та знань усіх учасників, включаючи викладача, підвищують мотивацію у навчанні та збільшують його ефективність.

Сучасні інформаційні технології дозволяють створювати, зберігати, переробляти інформацію та забезпечують ефективні способи іiі подання студентам, а це - потужний інструмент прискорення освітнього процесу висококваліфікованих фахівців з фізичної терапії. 
Журнал«Герспективитаіновації наукиљ

(Серія «Гедагогіка», Серія«ГЕихологія», Серія«Медицина»

№1(6) 2022

Ефективність інноваційних методик дозволяє урізноманітнити форми представлення навчального матеріалу, забезпечувати високий рівень наочності, звільняє від рутинної роботи, дає можливість викладачеві диференціювати рівень підготовки студента, стимулювати його пізнавальні інтереси. Інформаційні технології полегшують доступ до інформації, відкривають можливість варіативності навчальної діяльності, дозволяють за новим організувати взаємодію всіх суб'єктів навчання, побудувати освітню систему, в якій студент був би активним рівноправним учасником освітньої діяльності.

Інформаційні технології дозволяють давати ілюстрації найважливіших понять фізичної терапії. Це підвищення наочності, активізації пізнавальної діяльності студентів, поєднання механізмів вербально-логічного та образного мислення. Традиційні вимоги до навчальних занять (запам'ятати, вміти відтворити) трансформуються до базових інформаційних умінь типу пошуку знань (уміти знайти та застосувати під час вирішення поставлених завдань). Сучасні програми відкривають доступ передових джерел інформації електронних підручників, освітніх сайтів та систем дистанційного навчання. При цьому здійснюється і особистісно-орієнтований розвиток усіх учасників педагогічного процесу: студентів та викладачів. Інформаційні технології вимагають від викладача розвитку спеціальних навичок, прийомів педагогічної роботи, значно підвищують вимоги до якості навчальних матеріалів, що розробляються, через відкритість доступу до них студентів, інших викладачів та експертів.

Необхідно зазначити, що вища освіта має безперечну специфіку, яка полягає в тому, що кінцевий продукт - фахівець, здатний до професійної діяльності - формується за безпосередньої участі учня і тому вирішально залежить від зусиль самого студента, прояву ним власної ініціативи .

У ході такого навчання та взаємодії студенти набувають і так званих афективних здібностей, під якими маються на увазі навички міжособистісного спілкування, здібності роботи в команді, лідерські якості, навички постійного самовдосконалення. Роль викладача при цьому також зазнає змін, переходячи від носія знань до співпраці, його активність поступається місцем активності самих учнів.

Специфіка технології професійної підготовки, що застосовується під час викладання дисципліни "Теорія і практика фізичної терапії" проявляється в тому, що при проведенні заняття у вигляді "ситуаційного тренінгу" або розв'язання "ситуаційного завдання" можна досягти прогнозованих результатів. Робота в групі з аналізу ситуації дозволяє студентам не лише краще засвоїти матеріал, але й розглядати різноманітні можливості та підходи до вирішення того чи іншого практичного завдання чи проблеми.

У процесі вирішення клінічної задачі студенту потрібно актуалізувати знання, отримані раніше, а якщо не вистачає знань, то знайти їх та застосувати. При цьому нерідко сама проблема може не мати однозначного рішення, а 
вимагати різнобічних знань щодо проведення диференціальної діагностики захворювань, що дозволяє викладачеві планувати хід заняття.

Технології аналізу ситуацій дозволяють розвивати аналітичні здібності та критичне мислення, більш осмислено поєднувати теоретичні знання 3 практикою, формувати навички оцінки альтернативних варіантів в умовах невизначеності. Для практичної діяльності майбутнього фахівця 3 фізичної терапії важливе значення має i формування в процесі аналізу клінічних ситуацій певних комунікативних навичок, а саме: точність вираження власної точки зору та аргументації iї, формування навичок розв'язання комплексних завдань, проведення самооцінки тощо.

Даний варіант інтерактивного навчання дозволяє студентам реалізувати, 3 одного боку, отримані теоретичні знання, з іншого - відпрацювати практичні навички. Це дозволяє студенту застосувати на практиці вміння та навички при виборі тактики курації пацієнта та, найголовніше, набути впевненості при здійсненні ефективних дій в умовах реальної роботи в галузі фізичної терапії.

Використання методу аналізу клінічних ситуацій у викладанні теорії і практики фізичної терапії створює основу для вирішення проблем, сприяючи становленню майбутнього фізичного терапевта як кваліфікованого фахівця, різнобічно та творчо розвиненого та креативного фахівця.

Висновки. Використання інформаційних технологій викладання теорії i практики фізичної терапії $\epsilon$ одним із пріоритетних напрямків сьогодення. Інформаційні технології дозволяють удосконалювати методологію, зміст, методи та організаційні форми навчання 3 клінічних дисциплін, удосконалювати механізми управління педагогічним процесом. Сучасні інформаційні технології $\epsilon$ інструментом прискорення освітнього процесу, дозволяють створювати, зберігати та переробляти інформацію медичного призначення та представляти ії студентам для навчання та оцінки рівня знань.

Інформаційні технології дозволяють давати ілюстрації найважливіших понять фізичної терапії. Це підвищення наочності, активізації пізнавальної діяльності студентів, поєднання механізмів вербально-логічного та образного мислення. Традиційні вимоги до навчальних занять (запам'ятати, вміти відтворити) трансформуються до базових інформаційних умінь типу пошуку знань (уміти знайти та застосувати під час вирішення поставлених завдань). Сучасні програми відкривають доступ передових джерел інформації електронних підручників, освітніх сайтів та систем дистанційного навчання. При цьому здійснюється і особистісно-орієнтований розвиток усіх учасників педагогічного процесу: студентів та викладачів. Інформаційні технології вимагають від викладача розвитку спеціальних навичок, прийомів педагогічної роботи, значно підвищують вимоги до якості навчальних матеріалів, що розробляються, через відкритість доступу до них студентів, інших викладачів та експертів. У ході такого навчання та взаємодії студенти набувають і так званих афективних здібностей, під якими маються на увазі навички міжособистісного спілкування, здібності роботи в команді, лідерські якості, 
навички постійного самовдосконалення. Роль викладача при цьому також зазнає змін, переходячи від носія знань до співпраці, його активність поступається місцем активності самих учнів.

Специфіка технології професійної підготовки, що застосовується під час викладання дисципліни "Теорія і практика фізичної терапії" проявляється в тому, що при проведенні заняття у вигляді "ситуаційного тренінгу" або розв'язання "ситуаційного завдання" можна досягти прогнозованих результатів. Робота в групі з аналізу ситуації дозволяє студентам не лише краще засвоїти матеріал, але й розглядати різноманітні можливості та підходи до вирішення того чи іншого практичного завдання чи проблеми.

\section{Лimepamypa:}

1. Копочинська Ю. В. Теоретичні і методичні засади формування професійної ідентичності майбутніх фахівців з фізичної терапії, ерготерапії в закладах вищої освіти : дис. ... доктора пед. наук : 13.00.04 - теорія і методика професійної освіти / Національний педагогічний університет імені М. П. Драгоманова, Київ, 2021. 571 с.

2. Aboud, F. The effect of E: Learning on EFL teacher identity. International Journal of English Research. 2020. 6(2). P. 22-27.

3. Brown, A., Lawrence, J., Basson, M., Redmond, P. A conceptual framework to enhance student online learning and engagement in higher education. Higher Education Research \& Development. 2019. https://doi.org/10.1080/07294360.2020.1860912

4. Dhawan, S. Online learning: A panacea in the time of COVID-19 crisis. Journal of Educational Technology Systems. 2020. 14(1). P. 5-22.

5. Dreamson, N. Online design education: Meta-connective pedagogy. International Journal of Art \& Design Education. 2020. 39(3). P. 483-497. https://doi.org/10.1111/jade.12314.

6. Khalid, F. Students' identities and its relationships with their engagement in an online learning community. International Journal of Emerging Technologies in Learning. 2019. 14(5). P. 4-19.

7. Kwon, S., Kim, W., Bae, C. The identity changes in online learning and teaching: instructors, learners, and learning management systems. Int J Educ Technol High Educ. 2021. 18. P. 67. https://doi.org/10.1186/s41239-021-00304-8

8. Renz, A., Hilbig, R. Prerequisites for artificial intelligence in further education: identification of drivers, barriers, and business models of educational technology companies. Int J Educ Technol High Educ. 2020. 17. P. 14. https://doi.org/10.1186/s41239-020-00193-3

9. Santiago, B. J., Ramírez, J. M. O., Rodríguez-Reséndiz, J., Dector, A., García, R. G., González-Durán, J. E. E., Sánchez, F. F. Learning management system-based evaluation to determine academic efficiency performance. Sustainability. 2020. 12. P. 2-17.

\section{References:}

1. Kopochynska, Yu. V. (2021). Teoretychni i metodychni zasady formuvannia profesiinoi identychnosti maibutnikh fakhivtsiv $\mathrm{z}$ fizychnoi terapii, erhoterapii $\mathrm{v}$ zakladakh vyshchoi osvity [Theoretical and methodological principles of forming the professional identity of future specialists in physical therapy, occupational therapy in higher education] : dissertation of the doctor of pedagogical sciences. Theory and methods of vocational education. Kyiv: National Pedagogical Dragomanov University. [in Ukrainian]

2. Aboud, F. (2020). The effect of E: Learning on EFL teacher identity. International Journal of English Research, 6(2), 22-27. 
3. Brown, A., Lawrence, J., Basson, M., Redmond, P. (2019). A conceptual framework to enhance student online learning and engagement in higher education. Higher Education Research \& Development. https://doi.org/10.1080/07294360.2020.1860912

4. Dhawan, S. (2020). Online learning: A panacea in the time of COVID-19 crisis. Journal of Educational Technology Systems, 14(1), 5-22.

5. Dreamson, N. (2020). Online design education: Meta-connective pedagogy. International Journal of Art \& Design Education, 39(3), 483-497. https://doi.org/10.1111/jade.12314.

6. Khalid, F. (2019). Students' identities and its relationships with their engagement in an online learning community. International Journal of Emerging Technologies in Learning, 14(5), 4-19.

7. Kwon, S., Kim, W., Bae, C. (2021). The identity changes in online learning and teaching: instructors, learners, and learning management systems. Int J Educ Technol High Educ, 18, 67. https://doi.org/10.1186/s41239-021-00304-8

8. Renz, A., Hilbig, R. (2020). Prerequisites for artificial intelligence in further education: identification of drivers, barriers, and business models of educational technology companies. Int J Educ Technol High Educ, 17, 14. https://doi.org/10.1186/s41239-020-00193-3

9. Santiago, B. J., Ramírez, J. M. O., Rodríguez-Reséndiz, J., Dector, A., García, R. G., González-Durán, J. E. E., Sánchez, F. F. (2020). Learning management system-based evaluation to determine academic efficiency performance. Sustainability, 12, 2-17. 